\title{
Science journalism: Too close for comfort
}

\section{科学ジャ一ナリズムの歴史的変遷}

Boyce Rensberger Nature Vol. 459(1055-1056)/25 June 2009

100 年以上の歴史をもつ科学ジャーナリズムは、科学のチアリーダ一から監視役へと進歩・変遷を遂げてきた。

1 世紀以上前に誕生した科学ジャーナリズ ムは、その深い部分で重大な歴史的変化 を遂げてきた。それは現代の科学ジャーナ リストが認識しているよりも、はるかに根 源的な変容だった。今日の科学記者の中 には、情報源との関係が近すぎて困ると か、あるいは特定の分野に対して公平無 私の分析ができなくなっている、といった 不満を抱く人が少なくない。それはもっと もな態度だと私は思う。彼らにとって、科 学ジャーナリストという職業の誕生から現 在までの足跡を振り返ることは、必ずや何 らかの役に立つはずである。

1890 年代にはまだ、たぶん米国にも 英国にも専任の科学ジャーナリストは皆無 だった。しかし、パートタイムの科学ジャー ナリストなら有名な人物がいた。SF作家 H. G. Wells である。彼はサイエンスフィク ションを執筆する合間に、純粋な科学的知

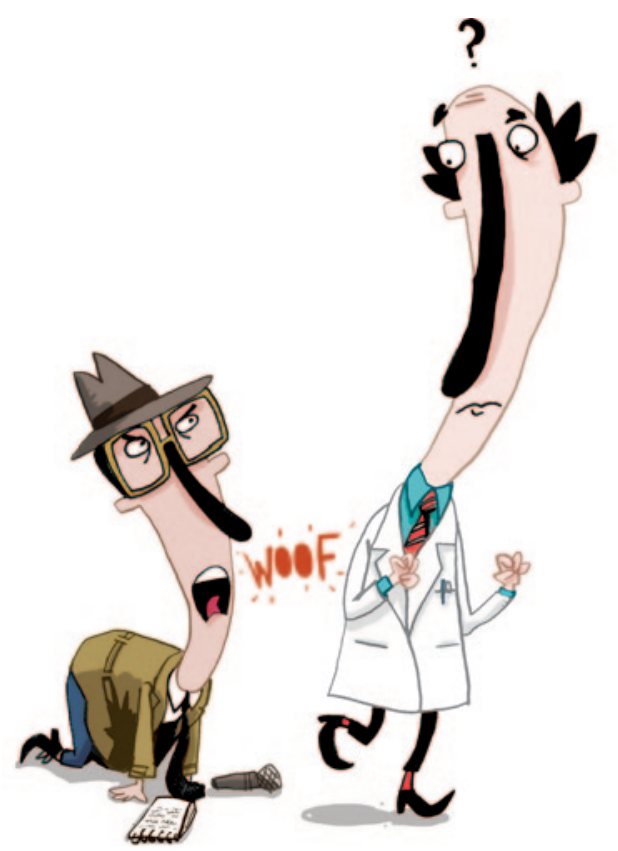

見について新聞記事を執筆していた。彼 の主張は「ライターは、科学者の専門用 語を翻訳し、文章技術を駆使して、専門 外の読者の関心を引きつける必要がある」 というものだった。1894 年に発行された Nature の中で、Wells は、今日「物語的ノ ンフィクション」とよばれている技法の必 要性を、次のように指摘している。「ポーの 『モルグ街の殺人事件』やコナン・ドイル の『シャーロックホームズ』シリーズのよ うな小説の根底にある構成の基本原理こ そ、科学ライターが指針とすべきものであ る」(Nature 50，300-301；1894 参照)。

現在のニューヨークタイムズ紙を創刊し た Adolph Ochs は、1904 年、伝説の 男 Carr Van Andaを編集局長に採用した。 この男はおそらく、20 世紀において科学 に対する最も鋭い知性と感覚を備えた新 聞社幹部だった。Van Anda は大学で天 文学と物理学を学び、自ら科学記事を執 筆するとともに、部下の記者たちにも科学 記事を書くよう奨励した。彼が強調したの は、正確な記事を書くことだった。彼につ いて頻繁に引用される逸話が残っている。 それは、同紙の記事で取り上げたアルバー ト・アインシュタインの講義における数学 的な誤りを、彼が印刷直前に訂正したと いうものだ。もちろんアインシュタインと 相談した上でのことではあったが。

当時の大部分の科学記者の仕事は、今 とは違って、専門用語を翻訳し、科学者や 医学界の第一人者の発言内容を説明する ことだった。その他、少数ではあるが、コー ネル大学 (米国、ニューヨーク州イサカ) で科学ジャーナリズム史を研究する Bruce

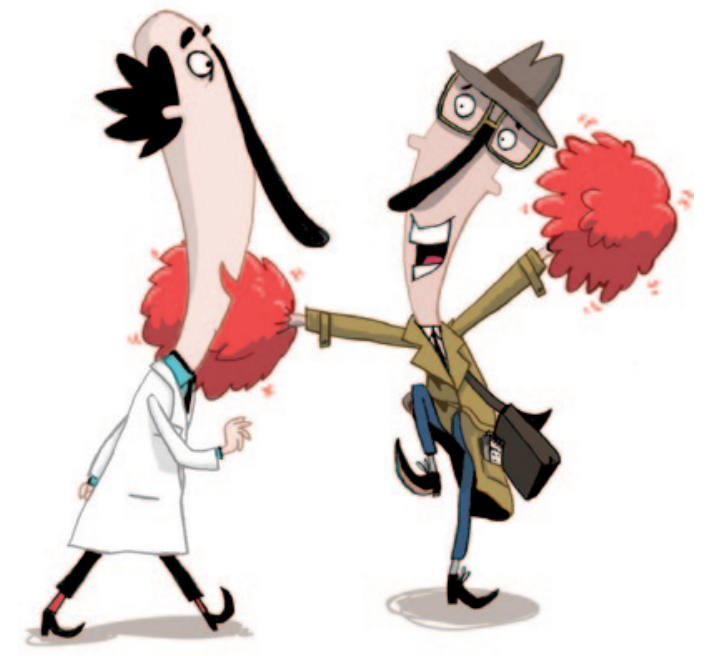

Lewenstein が指摘するような考え方をも つ人々もいた。すなわち、1930～ 1940 年代の米国の新聞社に所属する少数の科 学ジャーナリストたちは、社会を救済する 手段として科学を一般市民が受け入れるよ う、説得するのが自らの仕事だと信じてい た (B. V. Lewenstein Public Underst. Sci. 1，45-68；1992)。これは、米国史にお ける革新主義の時代 (Progressive Era) の産物・名残ともいえるものだった。革 新主義は 1890 年代から 1920 年代まで の米国を支配した考え方で、当時のあら ゆるタイプの知識人は、社会を完璧なも のにすることは可能であって、科学と技術 の驚異によって、文明を理想状態に導くこ とができると信じた。

米国の科学記者は、こうした責務を果 たすためには、科学者自身が科学記者を より真剣に受け入れる必要があると考え た。1934 年には科学著述者協会 (NASW) 
を設立し、自らの呼称についても、「ジャー ナリスト」や「レポーター」ではなく、明 確に「ライター」と名乗ったのである。こ のほうが、より専門性の高い職業というイ メージを与えることができると考えたから だ。NASWの会員 12 人全員は、自分た ちはエリート集団の一員であり、したがっ て安心して話をして欲しい、と科学者によ びかけた。そして、会員以外は「真の科 学ライター」ではないので、話をしないよ う忠告した。かくして、私が科学報道の「こ れはすごい! 時代 (Gee-Whiz Age)」と よぶ期間が始まった。この時代は、科学 の驚異と科学者への尊敬が重視・強調さ れ、進行中の科学研究に対する分析やそ の社会に対する影響の予測には、全く力 が注がれなかった。

1937 年、タイム誌の科学記者 George W. Gray は次のような言葉を残している。 科学ジャーナリズムは、「科学的手法を社 会大衆教育に不可欠な要素として組み込 むために、そして、そのような社会教育を 通して、科学的手法が文明的思考の普遍 的な要素となるために」尽力すべきである、 と。Gray は 1949 年に米国科学振興協会 (AAAS) から表彰されたが、その時、彼

著作権等の理由により画像を掲載することができません。

William Laurence (左) は、J. Robert Oppenheimer (右) の原子爆弾に関する記事を執筆する一方で、米国陸軍省の プレスリリースも作成した。
は「一番大事なのは、科学者本人たちか ら認められることなのだ」とまくしたてた。 この時代の大半の期間、科学記者は 1 つの神話を追い求めていた。Lewenstein によれば、それは「科学者と科学ライ ターの正しい関係は、両者の間に信頼と 尊敬が存在すること」というものだった。 その典型的な例が、科学記者 William Laurence による世界初の原子爆弾開発を めざしたマンハッタン計画の記事にみるこ とができる。

ニューヨークタイムズに記事を執筆して いた Laurence は、一般市民が科学の真 価を認めるよう望んでおり、彼のこの希望 もまたよく知られていた。そのこともあっ て、米国陸軍省（現在の国防総省）は、 マンハッタン計画と日本での原爆投下の機 密を知らせる唯一の記者として、彼を選ん だのである。実際、Laurence は軍内部 に組み込まれた初期の科学ジャーナリス卜 の一人だった。偶然にも彼は、第 33 代 トルーマン大統領と陸軍省のために原子 爆弾に関するプレスリリースを作成して、 米国政府から給与を受け取っていたのだ。 信じがたいことに、Laurence が政府のた めに㗢いていた事実は秘密にされなかっ た。今日のジャーナリストならば重大な利 益相反行為と考えるだろうが、当時は誰 も違和感をもたなかったのである。

\section{チアリーダーから監視役へ}

広島と長崎に原爆が投下された後、爆風 が及んだ地域の外側であっても、多くの 人々が病気になって死んでいるという噂が 立った。そのため、陸軍省はニューメキシ コ州のアラモゴード基地で記者会見を開 いた。この件に関する Laurence の記事 は次のように始まる。「地球上で初の原子 爆弾の爆破実験が行われ、文明の新時代 が始まった歴史的な、ここニューメキシコ の地は、爆弾投下日以降も続出している 死者の原因が放射能だとする日本の宣伝 工作に対する、最も有効な答えである」。 そしてこの記事で、アラモゴード基地の見
学によって「そうした主張がウソであるこ とが証明される」だろうと書いた。ジャー ナリズム界は、Laurence が科学ジャー ナリズムの極致を体現していると見なし、 Laurence は 1946 年にピューリッツァー 賞を受賞した。

1950 年代に入ると、科学ジャーナリス トは、科学の実用的意義や社会への影響 よりも、科学的発見、すなわち科学自体 の喜びの方が重視されるべきである、と いう信念を記すことが多くなった。NASW 会員の間では、いかにすれば科学ジャー ナリズムが「より効果的」なものとなるか、 方法論についての議論が多くなった。しか しその目的は、科学ジャーナリズムが科学 の監視役としての機能を強めるためでは なく、従来よりも幅広い層の国民に科学 の真価を認めさせるためであった。私は、 この姿勢・態度こそが、当時の新聞社幹 部が自社の科学ライターや医事ライターに 不信感を持ち始めた理由だと考えている。 結局のところ、ニュース編集室では、どの 分野の記者であっても、取材対象に対し ては公平無私、時には挑戦的ともいえる 姿勢によって評価されるからである。

ほどなく、科学ジャーナリズムの「これ はすごい! 時代」に亀裂が生じ始めた。 1962 年、レイチェル・カーソンの『沈黙 の春 (Silent Spring)』が出版され、殺 虫剂 DDTによって鳥類の卵の殼が弱くな り、野生生物の殺践につながることが浮き 彫りにされた。ところが殺虫剤は、科学技 術の驚異であり、一般市民が称賛・受容 すべきものとして報じられてきたため、科 学ジャーナリストは葛藤することになった。 『沈黙の春』は感情的で偏見にとらわれ ている、と撖しく批判した者もいた。Time や Fortune に記事を書いていた Lawrence Lessing は、カーソンを攻撃し、科学の最 高の著述は、米国化学会や賢明な化学業 界との共同作業によって達成されると主張 した。そこでは「現役の科学者と科学ライ ターが対話を深め、公共の利益にまで高 めていく」という。しかし、『沈黙の春』と 
彼女の「産業界の主張を無批判に受け取 るべきではない」という見解は、環境保護 運動の立上げだけでなく、環境報道という 新分野を生み出すことにもなった。環境分 野の記者は、科学者、特に産業界から資 金提供を受けている研究に対して、より批 判的な姿勢をとるようになった。

1970 年代には、技術に潜むマイナス 面がますます表に現れてきた。その象徵 ともいえるのが、ペンシルベニア州ハリス バーグ近郊のスリーマイル島原子力発電 所における原子炉溶融事故であった。そ の頃には、科学ジャーナリストが記事を書 く際に、記事のテーマがもつ社会的・政 治的影響を無視することはできなくなって いた。こうして、科学ジャーナリズム史に おける次の重要な時代である「監視役と しての時代」が始まった。科学記者の姿は、 ニュース編集室の他分野の同僚にかなり 近づいていったのである。

\section{紙メディアの衰退}

この時代に、科学ジャーナリズムは量的に もブーム、繁栄期を迎えた。1978 年に ニューヨークタイムズの科学欄が誕生した
のは、その先駆けだった。ある統計によ れば、このブームがピークに達した 1987 年には、147 の新聞に少なくとも週 1 回 の科学記事のページが作られ、老舗の Scientific American と Science News に加え て、4つのポピュラー科学雑誌が創刊さ れた。しかし残念ながら、このブームは 長続きしなかった。1980 年代後半になっ て雑誌の上げ潮期は終わりを告げ、現在 も老舗誌のはざまで健闘している Discover を除き、新興雑誌はすべて黒字化を果た せず廃刊となった。新聞の科学欄の数も 減り始め、今日も生き残っているわずかの 科学欄を残して、すべて消滅した。

「デジタル時代」に入ったことが明らか な現代にあって、ジャーナリズムの定義 そのものが変化しつつある。そして、そ の方向性も不透明だ。科学ジャーナリズ ムは、科学界の栄光のために仕える役割 をやめ、独立性を取り戻し、一般市民に 対して新たな責任を果たすようになってい る。現在、伝統的な報道機関は衰退しつ つあり、多くのジャーナリストは、インター ネット上で自ら記事を発信し、全面的な独 立を獲得して、一般市民との直接のつな
がりを得ている。一方で、科学者もイン ターネットを利用して、ジャーナリストを完 全に飛び越えて、その研究成果や研究計 画を一般市民に直接提示している。読者 にとっては、公平無私な情報源と何らかの 思惑のある情報源とを見分けることが、ま すます難しくなってきている。

科学ジャーナリストが、再び、社会にとっ て意義ある存在となるには、新しいメディ アを習得するだけでなく、新知見を解析、 解釈し、資金提供者の意図までをも見抜 くために、十分な科学知識を学ばなけれ ばならない。しかし事はそれだけではすま ない。実用化までにはまだ時間のある開 発段階の新技術であっても、一石を投じら れる間に、その技術の社会的影響力を予 測・予見できなければならないのである。 (菊川要 訳)

Boyce Rensberger は、1998〜 2008 年にマサチュー セッツ工科大学（米国ケンブリッジ）の「ナイト科学 ジャーナリズム・フェローシップ」プログラムのディ レクターをつとめ、科学記者として 32 年間の実績が ある。主にワシントンポスト紙とニューヨークタイム ズ紙の記事を執筆した。 